Article

\title{
Acetylcholinesterase-Inhibiting Activity of Pyrrole Derivatives from a Novel Marine Gliding Bacterium, Rapidithrix thailandica
}

\author{
Yutthapong Sangnoi ${ }^{1}$, Oraphan Sakulkeo ${ }^{2}$, Supreeya Yuenyongsawad ${ }^{2}$, \\ Akkharawit Kanjana-opas ${ }^{1,4}$, Kornkanok Ingkaninan ${ }^{3,4}$, Anuchit Plubrukarn ${ }^{2,4, *}$ and \\ Khanit Suwanborirux ${ }^{4}$
}

1 Department of Industrial Biotechnology, Faculty of Agro-Industry, Prince of Songkla University, Hat-Yai, Songkla 90112, Thailand

2 Marine Natural Products Research Unit, Department of Pharmacognosy and Pharmaceutical Botany, Faculty of Pharmaceutical Sciences, Prince of Songkla University, Hat-Yai, Songkhla 90112, Thailand

3 Department of Pharmaceutical Chemistry and Pharmacognosy, Faculty of Pharmaceutical Sciences, Naresuan University, Phitsanulok 65000, Thailand

4 Center for Bioactive Natural Products from Marine Organisms and Endophytic Fungi (BNPME), Department of Pharmacognosy, Faculty of Pharmaceutical Sciences, Chulalongkorn University, Patumwan, Bangkok 10330, Thailand

* Author to whom correspondence should be addressed; E-mail: anuchit.pl@psu.ac.th

Received: 2 September 2008; in revised form: 3 October 2008 / Accepted: 8 October 2008 / Published: 13 October 2008

\begin{abstract}
Acetylcholinesterase-inhibiting activity of marinoquinoline A (1), a new pyrroloquinoline from a novel species of a marine gliding bacterium Rapidithrix thailandica, was assessed $\left(\mathrm{IC}_{50} 4.9 \mu \mathrm{M}\right)$. Two related pyrrole derivatives, 3-(2'aminophenyl)-pyrrole (3) and 2,2-dimethyl-pyrrolo-1,2-dihydroquinoline (4), were also isolated from two other strains of $R$. thailandica. The isolation of $\mathbf{3}$ from a natural source is reported here for the first time. Compound $\mathbf{4}$ was proposed to be an isolation artifact derived from 3. The two isolated compounds were virtually inactive in the acetylcholinesterase-inhibitory assay (enzyme inhibition $<30 \%$ at $0.1 \mathrm{~g} \mathrm{~L}^{-1}$ ).
\end{abstract}

Keywords: pyrroloquinolines; phenylpyrroles; gliding bacteria; Rapidithrix thailandica; acetylcholinesterase inhibitors 


\section{Introduction}

One of the most important roles of acetylcholine in the brain is to govern the connectivity among neurons, thereby regulating the brain's cognitive functions. A deficit in acetylcholine, especially in the basal forebrains, is a neurochemical characteristic of patients clinically diagnosed with Alzheimer's disease (AD). Using acetylcholinesterase (AChE) inhibitors to retard the catabolic hydrolysis of acetylcholine, therefore compensating such deficiency particularly at the synaptic terminals, has been suggested as one of the most direct remedies for AD treatment. To date, only three AChE inhibitors; donepezil, rivastigmine, and galantamine, have been approved by US FDA for the treatment of $\mathrm{AD}$. Whereas it is arguable whether such drugs provide a long-term treatment or are merely a symptom intervention, they are one of only a few effective approaches available for the treatment of $\mathrm{AD}[1,2]$.

Recently, we reported the isolation and structure elucidation of marinoquinoline A (1), a new alkaloid possessing an unprecedented pyrrolo[2,3-c] quinoline skeleton from a novel marine gliding bacterium Rapidithrix thailandica [3,4]. The structural similarity between $\mathbf{1}$ and tacrine (2), a potent AChE inhibitor, prompted us to subject the compound to the AChE inhibiting assay, as well as to search for additional pyrrole/pyrroloquinoline derivatives from the bacterium. Here, the isolation and structure determination of the phenylpyrrole analogs of $\mathbf{1}$ will be reported, along with the AChEinhibiting activity of $\mathbf{1}$ and related compounds.

\section{Results and Discussion}

Marinoquinoline A (1) was obtained from the gliding bacterium $R$. thailandica TISTR 1742 as reported earlier [3]. Given the close resemblance between $\mathbf{1}$ and 2, we speculated that $\mathbf{1}$ might bind to the enzyme $\mathrm{AChE}$ in a manner similar to that of $\mathbf{2}$. Consequently, $\mathbf{1}$ was assayed against $\mathrm{AChE}$ using Torpedo californica AChE. As expected, the compound exhibited a strong inhibition with an $\mathrm{IC}_{50}$ of $4.9 \pm 0.9 \mu \mathrm{M}$ (referred to standard galantamine, $\mathrm{IC}_{50} 0.6 \pm 0.1 \mu \mathrm{M}$ ) with no appreciable cytotoxicity against the panel of cancer cell lines ( $>80 \%$ cell viability at $20 \mu \mathrm{M})$.

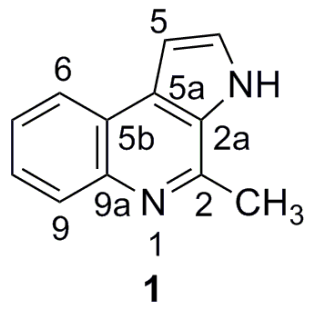<smiles>Nc1c2c(nc3ccccc13)CCCC2</smiles><smiles>[R13]c1c[nH]cc1-c1cccc([R])c1[R]</smiles><smiles>CC1(C)Nc2ccccc2-c2cc[nH]c21</smiles>

$$
\begin{aligned}
& 3 ; R^{1}=N_{2} ; R^{2}=R^{3}=H \\
& 5 ; R^{1}=N O_{2} ; R^{2}=R^{3}=C l
\end{aligned}
$$$$
4
$$ 
Based on the promising results, two other strains of $R$. thailandica were selected for the chemical investigation in an effort to discover related pyrrole/pyrroloquinoline derivatives. The gliding bacterial strains TISTR 1749 and SH5.13.2 were separately isolated from a submerged sea grass blade collected from Fossil Shell Beach Park, Krabi Province, and from debris collected from Koh-Kham, Chonburi Province, respectively. The 16S rDNA analysis of the bacterial isolates suggested that they were identical to each other. The BLAST search with the 16S rDNA gene sequences in GenBank database indicated that both strains belonged to the gliding bacterium $R$. thailandica, gen. nov., sp. nov. (family Flammeovirgaceae), with $99 \%$ similarity in gene sequences to the type strain TISTR $1750^{\mathrm{T}}[4]$.

The large scale fermentations of strains TISTR 1749 and SH5.13.2 were carried out in skim milk and CY media, respectively. Amberlite XAD-16, added to the fermentation broths of each strain, was harvested and eluted with $\mathrm{MeOH}$, and each extract was subjected to the further chromatographic separation. Extract from the strain TISTR 1749 yielded $\mathbf{3}$ and 4, whereas that of SH5.13.2 yielded $\mathbf{3}$ as the main product.

Compound 3 possesses a molecular formula of $\mathrm{C}_{10} \mathrm{H}_{10} \mathrm{~N}_{2}$ according to the molecular ion signal at $\mathrm{m} / \mathrm{z} 158$ observable in the EI mass spectrum. This was confirmed by the high resolution mass of 158.0852 (EI; calc for $\mathrm{C}_{10} \mathrm{H}_{10} \mathrm{~N}_{2}$ 158.0842). The ${ }^{1} \mathrm{H}$ NMR spectrum (500 MHz, DMSO- $d_{6}$, Table 1) showed nine resonances, seven of which belonged to two aromatic spin systems, while the other two were exchangeable proton signals. The first aromatic spin system, resonating at $\delta 6.55$ (ddd, $J=7.5$, 7.3, $1.3 \mathrm{~Hz}$; H-5'), 6.69 (dd, $J=7.9,1.3 \mathrm{~Hz}$; H-3'), 6.88 (ddd, $J=7.9,7.3,1.3 \mathrm{~Hz}$; H-4'), and 7.10 (dd, $J=7.5,1.5 \mathrm{~Hz}$; H-6'), was characteristic to a 1,2-disubstituted benzene ring. Another spin system was elucidated as 3-substituted pyrrole moiety according to the characteristic proton signals at $\delta 6.25$ (ddd, $J=2.5,2.3,<1 \mathrm{~Hz} ; \mathrm{H}-4), 6.83$ (ddd, $J=2.5,2.3,2.3 \mathrm{~Hz} ; \mathrm{H}-5$ ), and 6.96 (ddd, $J=2.3,2.3,<1 \mathrm{~Hz}$; H2). This agreed well with the observation of the low-fielded exchangeable proton at $\delta 10.90$ (br s), typically assigned to $\mathrm{H}-1$ of pyrrole. The connection of the two aromatic rings was achieved via the HMBC long-range correlation from C-3 to H-6'. The presence of a primary amino group was deduced from the characteristic IR absorption band at $v_{\max } 3400 \mathrm{~cm}^{-1}$, and from the exchangeable proton resonance at $\delta 4.70\left(\right.$ br s, $\left.2 \mathrm{H} ; 2^{\prime}-\mathrm{NH}_{2}\right)$. Attachment of the amino group onto C-2' $(\delta 144.8)$ of the phenyl ring furnished the structure of $\mathbf{3}$ as 3-(2'-aminophenyl)-pyrrole. The nOe between each pair of protons along the circumference of the structure, i.e., H-1 $\leftrightarrow \mathrm{H}-2 \leftrightarrow 2^{\prime}-\mathrm{NH}_{2} \leftrightarrow \mathrm{H}-3^{\prime} \leftrightarrow \mathrm{H}-4^{\prime} \leftrightarrow \mathrm{H}-5^{\prime} \leftrightarrow$ H-6' $\leftrightarrow$ H-4 $\leftrightarrow$ H-5 $\leftrightarrow$ H-1, strongly supported the proposed structure. The structure of $\mathbf{3}$ has been proposed as one of theoretical biosynthetic intermediates of the antibiotic pyrronitrin (5) [5-7], previously reported from several pseudomonads and related bacteria [5,8-10]. This hypothesis was challenged in a recent report by Kirner et al [11], who suggested that 3 was in fact either a side product or biosynthetic dead-end of $\mathbf{5}$. In either case, however, $\mathbf{3}$ has never been actually isolated from any natural sources.

The molecular formula of 4 was proposed to be $\mathrm{C}_{13} \mathrm{H}_{14} \mathrm{~N}_{2}$ as deduced from the high resolution mass at $m / z 198.1122$ in the HR-EI mass spectrum (calc for $\mathrm{C}_{13} \mathrm{H}_{14} \mathrm{~N}_{2}$ 198.1154). From the ${ }^{1} \mathrm{H}$ NMR spectrum (500 MHz, DMSO- $d_{6}$, Table 2), seven proton resonances characteristic of a 1,2-disubstituted benzene $(\delta 6.45$, ddd, $J=7.7,7.5,1.0 \mathrm{~Hz}, \mathrm{H}-7 ; 6.50$, dd, $J=7.9,1.0 \mathrm{~Hz}, \mathrm{H}-9 ; 6.73$, ddd, $J=7.9,7.7$, $1.3 \mathrm{~Hz}, \mathrm{H}-8$; and 7.08, dd, $J=7.5,1.3 \mathrm{~Hz}, \mathrm{H}-6)$ and of a 2,3-disubstituted pyrrole $(\delta 6.20, \mathrm{dd}, J=2.6$, $2.4 \mathrm{~Hz}, \mathrm{H}-5$; 6.64, dd, $J=2.8,2.6 \mathrm{~Hz}, \mathrm{H}-4$; and 10.74, br s, H-1) suggested that 3 and 4 were closely 
related. The 40 mass units higher than that of $\mathbf{3}$, and the additional NMR signals, which include those of a quarternary carbon at $\delta 52.1(\mathrm{C}-2)$ and two geminal methyl at $\delta_{\mathrm{H}} 1.42\left(\mathrm{~s}, 6 \mathrm{H} ; 2-\mathrm{CH}_{3}\right)$ and $\delta_{\mathrm{C}} 30.6$ (2C), indicated that 4 was a dimethyl dihydroquinoline analog of $\mathbf{3}$. The structure of $\mathbf{4}$ was therefore proposed as 2,2-dimethyl-pyrrolo-1,2-dihydroquinoline. Also, similar to $\mathbf{3}$, a network of nOes along the circumference of the structure was observed, which strongly supported the proposed structure of 4 .

Table 1. NMR spectral data of 3 (DMSO- $d_{6} ; 500 \mathrm{MHz}$ for $\left.{ }^{1} \mathrm{H}\right)$.

\begin{tabular}{ccc}
\hline position & ${ }^{1} \mathrm{H}^{\mathrm{a}}$ (mult.; $J$ in Hz) & ${ }^{13} \mathrm{C}$ (mult.) \\
\hline 1 & $10.90($ br s) & - \\
2 & $6.96(\mathrm{ddd} ; 2.3,2.3,<1)$ & $115.8(\mathrm{CH})$ \\
3 & - & $121.1(\mathrm{C})$ \\
4 & $6.25(\mathrm{ddd} ; 2.5,2.3,<1)$ & $107.3(\mathrm{CH})$ \\
5 & $6.83(\mathrm{ddd} ; 2.5,2.3,2.3)$ & $118.3(\mathrm{CH})$ \\
$1^{\prime}$ & - & $121.6(\mathrm{C})$ \\
$2^{\prime}$ & - & $144.8(\mathrm{C})$ \\
$3^{\prime}$ & $6.69(\mathrm{dd} ; 7.9,1.3)$ & $115.2(\mathrm{CH})$ \\
$4^{\prime}$ & $6.88(\mathrm{ddd} ; 7.9,7.3,1.5)$ & $126.2(\mathrm{CH})$ \\
$5^{\prime}$ & $6.55(\mathrm{ddd} ; 7.5,7.3,1.3)$ & $116.9(\mathrm{CH})$ \\
$6^{\prime}$ & $7.10(\mathrm{dd} ; 7.5,1.5)$ & $128.9(\mathrm{CH})$ \\
$2^{\prime}-\mathrm{NH}_{2}$ & $4.20($ br s; $2 \mathrm{H})$ & - \\
\hline Note: ${ }^{\mathrm{a}}$ Unless stated otherwise, each proton signal integrated as 1 H.
\end{tabular}

Table 2. NMR spectral data of 4 (DMSO- $d_{6} ; 500 \mathrm{MHz}$ for $\left.{ }^{1} \mathrm{H}\right)$.

\begin{tabular}{ccc}
\hline position & ${ }^{1} \mathrm{H}^{\mathrm{a}}$ (mult.; $J$ in Hz) & ${ }^{13} \mathrm{C}^{\mathrm{b}}$ (mult.) \\
\hline 1 & $5.70($ br s) & - \\
2 & - & $52.1(\mathrm{C})$ \\
$2 \mathrm{a}$ & - & $132.2(\mathrm{C})$ \\
3 & $10.74($ br s) & - \\
4 & $6.64(\mathrm{dd} ; 2.8,2.6)$ & $117.8(\mathrm{CH})$ \\
5 & $6.20(\mathrm{dd} ; 2.6,2.4)$ & $101.5(\mathrm{CH})$ \\
$5 \mathrm{a}$ & - & $113.5(\mathrm{C})$ \\
$5 \mathrm{~b}$ & - & $119.1(\mathrm{C})$ \\
6 & $7.08(\mathrm{dd} ; 7.5,1.3)$ & $121.0(\mathrm{CH})$ \\
7 & $6.45(\mathrm{ddd} ; 7.7,7.5,1.0)$ & $116.2(\mathrm{CH})$ \\
8 & $6.73(\mathrm{ddd} ; 7.9,7.7,1.3)$ & $125.0(\mathrm{CH})$ \\
9 & $6.50(\mathrm{dd} ; 7.9,1.0)$ & $112.7(\mathrm{CH})$ \\
$9 \mathrm{a}$ & - & $141.7(\mathrm{C})$ \\
$2-\mathrm{CH} 3$ & $1.42(\mathrm{~s} ; 6 \mathrm{H})$ & $30.6(\mathrm{CH}, 2 \mathrm{C})$ \\
\hline Note: ${ }^{\mathrm{a}}$ Unless stated otherwise, each proton signal integrated as $1 \mathrm{H}$. \\
${ }^{b}$ Unless stated otherwise, each carbon signal is equivalent to $1 \mathrm{C}$.
\end{tabular}

Whereas the fermentation broth of strain TIRTR 1749 led to the isolation of two major components, that of SH5.13.2 primarily yielded only 3. The difference in the chemical compositions between the two strains raised the questions whether 4 was genuinely produced by $R$. thailandica TISTR 1749 or whether the compound was in fact an isolation artifact. Careful examination of the ${ }^{1} \mathrm{H}$ NMR spectra of 
the $\mathrm{MeOH}$ extract and subsequent fractions showed that only after the first chromatographic step, in which acetone was extensively used, were all the resonances related to 4 , especially the prominent methyl signal, observable. This suggested that $\mathbf{4}$ was potentially an artifact, presumably generated from $\mathrm{SiO}_{2}$-catalyzed Pictet-Spengler reaction between $\mathbf{3}$ and acetone. This was also supported by the absence of $\mathbf{4}$ in the extract from strain SH5.13.2, where acetone was avoided.

The AChE inhibitory activity and cytotoxicity of $\mathbf{3}$ and $\mathbf{4}$ were assessed. Surprisingly, both were inactive in the AChE inhibition and in the cytotoxicity bioassays (enzyme inhibition $<30 \%$ at $0.1 \mathrm{~g} \mathrm{~L}^{-}$ ${ }^{1}$; > 80\% cell viability at $20 \mathrm{~g} \mathrm{~L}^{-1}$, respectively). Despite sharing a related skeleton, the three compounds exhibited different activities. It is proposed here that the binding behavior to AChE of the pyrroloquinolines may relate to the extended aromaticity of the quinoline moiety of $\mathbf{2}$, which may have $\pi, \pi$-interaction in the gorge of AChE $[12,13]$.

In summary, we have demonstrated the potential of $\mathbf{1}$ as a new and potent AChE inhibitor. The investigation of two other strains of the novel marine gliding bacterium $R$. thailandica also led to the isolation of pyrrole derivatives, $\mathbf{3}$ and $\mathbf{4}$. Although $\mathbf{4}$ was suggested here as a possible isolation artifact generated from the condensation between $\mathbf{3}$ and acetone, the structures of the two isolated compounds have nonetheless never been reported from any natural and wild-type bioresources. In addition, without any intermediates related to $\mathbf{5}$ observable in the extract, the isolation of $\mathbf{3}$ as a major component from the marine gliding bacterium confirms the previous conclusion contributed in [11] that, unless produced from otherwise entirely different biosynthetic pathway, $\mathbf{3}$ (and presumably $\mathbf{1}$ ) can be presumed as a biosynthetic dead-end branched from that of $\mathbf{5}$, which are commonly found in several terrestrial bacteria.

\section{Experimental}

\subsection{General}

Unless stated otherwise, all chemicals, chromatographic solvents, and media were used as purchased. Sea water for all media preparation was filtered through cotton plug before used. The classical chromatographic separations were all performed using $\mathrm{SiO}_{2}$ (Scharlau ${ }^{\circledR}, 230-400$ mesh), whereas the size-exclusion one was operated on a Sephadex LH20 (GE Helathcare ${ }^{\circledR}$ ) column. Preparative HPLC was performed on a Water ${ }^{\circledR}$ 600E multisolvent delivery system, which was connected to a Water $^{\circledR} 484 \mathrm{UV}$ detector, and a Rheodyne ${ }^{\circledR} 7125$ injector port. IR spectra were obtained from a Jasco IR-810 infrared spectrometer. UV spectra were measured on a Spectronic Genesys 5 spectrometer. Mass spectra were operated on a Micromass LCT mass spectrometer. The NMR experiments were performed on a 500-MHz FT-NMR Varian Unity Inova 500 spectrometer, and were all referenced to the solvent signals (DMSO- $d_{6} ; \delta 2.49$ of trace $\mathrm{C}_{2} \mathrm{D}_{5} \mathrm{HSO}$ for ${ }^{1} \mathrm{H} ; \delta 39.7$ for ${ }^{13} \mathrm{C}$ ) as the internal standard.

\subsection{Bacterial isolation and purification}

The gliding bacteria TISTR 1749 and SH5.13.2 were isolated from a submerged sea grass blade collected from Fossil Shell Beach Park, Krabi Province, and from debris collected from Koh-Kham, 
Chonburi Province, respectively. For each isolate, a small piece of the collected specimen was cut and allowed to stand at an ambient temperature on a Petri dish of either SWG medium (for TISTR 1749) containing ( $\mathrm{g} \mathrm{L}^{-1}$ of sea water) monosodium $L$-glutamate (1), $\mathrm{NH}_{4} \mathrm{NO}_{3}(0.01), \mathrm{K}_{2} \mathrm{HPO}_{4}(0.01)$, agar (15) [14]; or a crystal violet-supplemented $\left(1 \mathrm{~g} \mathrm{~L}^{-1}\right) \mathrm{SWG}$ medium (for SH5.13.2) [modified from 15]. Once swarm colonies were observed, a cut piece of agar medium bearing one clean edge of each colony was transferred to a new subculture plate of $\mathrm{SAP}_{2}$ solid medium, containing $\left(\mathrm{g} \mathrm{L}^{-1}\right.$ of sea water) tryptone (1) and agar (15) [14, modified from 16]. The pure culture of the strain TISTR 1749 was obtained by means of micromanipulation technique [3,14], whereas that of SH5.13.2 was via repeated subculturing on $\mathrm{SAP}_{2}$ medium at ambient temperature. The reference culture of the strain TISTR 1749 was lodged at the culture collection of Thailand Institute of Scientific and Technological Research, Pathum-Thani, Thailand, and that of SH5.13.2 was at the Marine Biotechnology Laboratory, Department of Industrial Biotechnology, Faculty of Agro-Industry, Prince of Songkla University, Songkhla, Thailand.

\subsection{Taxonomic identification}

The taxonomic identification of both strains was based on the 16S rDNA analysis, performed as described in $[3,14]$. In brief, the $16 \mathrm{~S}$ rDNA was amplified by PCR technique using the $16 \mathrm{~S}$ rDNA universal primers BF1 and BR1. The purification of the PCR products was carried out using GFX PCR DNA and gel band purification kit (Amersham ${ }^{\circledR}$ ). Sequencing reaction was performed using the ABI PRISM BigDye Terminator cycle sequencing kit (Applied Biosystem ${ }^{\circledR}$ ). Sequencing was edited and assembled using the BioEdit program [17] and partial 16S rDNA sequences were compared with those available in the DNA databases using the BLASTN algorithm for close evolutionary relatives. The complete 16S rDNA sequences determined for representative strains of each group were aligned with the sequences of reference organisms derived from the database using the ClustalX 1.8.

\subsection{Large scale fermentation}

The medium for pre-culture and large-scale production of each strain of the gliding bacteria was as followed; $\mathrm{SAP}_{2}$ liquid medium ( $\mathrm{g} \mathrm{L}^{-1}$ of sea water) containing tryptone (1), yeast extract (1) [14, modified from 16]; CY medium ( $\mathrm{g} \mathrm{L}^{-1}$ of sea water) containing casitone (10), malt extract (2), yeast extract (1) [modified from 18]; skim milk medium $\left(\mathrm{g} \mathrm{L}^{-1}\right.$ of sea water) containing skim milk powder (5), yeast extract (3) [modified from 19].

The pre-culture of each bacterial strain was performed separately in 250-mL flasks each containing $30 \mathrm{~mL}$ of $\mathrm{SAP}_{2}$ liquid medium $\left(72 \mathrm{~h}, 25^{\circ} \mathrm{C}, 200 \mathrm{rev} \mathrm{min}^{-1}\right)$. A $5-\mathrm{mL}$ portion of the pre-culture broth from each strain was then separately transferred into a $250-\mathrm{mL}$ flask $(\times 80)$ of $100-\mathrm{mL}$ production medium as stated accordingly. An in promptu extraction was carried out using amberlite XAD-16 resins ( $2 \mathrm{~g}$ per $100 \mathrm{~mL}$ medium), added prior to sterilizing of each aforementioned production medium. After a 7-day incubation $\left(25^{\circ} \mathrm{C}, 200 \mathrm{rev} \mathrm{min}^{-1}\right)$, the resin beads from each strain were separately harvested via nylon mesh, rinsed with water, and extracted with $\mathrm{MeOH}(2 \times 100 \mathrm{~mL})$. 


\subsection{Extraction and compound isolation}

The isolation of $\mathbf{1}$ was as per our previous report. The identification was performed on the basis of spectral analysis, from which all impurities were undetectable.

The $\mathrm{MeOH}$ extract from the fermentation broth of the strain TISTR 1749 was subjected to a solvent partitioning protocol to yield hexane-, $\mathrm{CH}_{2} \mathrm{Cl}_{2-}$, and $n$-BuOH-extracts. The $\mathrm{CH}_{2} \mathrm{Cl}_{2}$-extract, which showed prominent ${ }^{1} \mathrm{H}$ NMR signals for phenylpyrroles, was selected for the further isolation. The chromatography of the extract on a $\mathrm{SiO}_{2}$ column (step gradient solvents, ramping from 20 to $30 \%$ acetone in hexane, then 5 to $50 \% \mathrm{MeOH}$ in $\left.\mathrm{CH}_{2} \mathrm{Cl}_{2}\right)$, then on a $\mathrm{SiO}_{2} \mathrm{HPLC}$ column $(250 \times 7 \mathrm{~mm}$ Econosil $^{\circledR}, 10 \mu \mathrm{m}$; continuous gradient 5 to $35 \% i-\mathrm{PrOH}$ in hexane in $15 \mathrm{~min}, 2 \mathrm{~mL} \mathrm{~min}{ }^{-1} ; 254 \mathrm{~nm}$ ) yielded 3 (12 $\left.\mathrm{mg} ; t_{\mathrm{R}} 19 \mathrm{~min}\right)$ and $4\left(27 \mathrm{mg} ; t_{\mathrm{R}} 13 \mathrm{~min}\right)$.

The MeOH extract from the broth of SH5.13.2 was directly chromatographed over Sephadex LH20 (MeOH), followed by RP-C18 HPLC (250×10 mm Phenomenax ${ }^{\circledR}, 10 \mu \mathrm{m} ; 70 \%$ aq MeOH, $5 \mathrm{~mL} \mathrm{~min}^{-1}$; $210 \mathrm{~nm})$, and 3 (35 $\left.\mathrm{mg} ; t_{\mathrm{R}} 31 \mathrm{~min}\right)$ was obtained.

3-(2'-Aminophenyl)-pyrrole (3). Brownish orange glass; UV (MeOH) $\lambda_{\max }(\log \varepsilon) 212$ (4.07), 302 (3.34) nm; IR (thin film) $v_{\max } 3400,2910,1610 \mathrm{~cm}^{-1}$; EIMS $m / z$ (\% relative intensity) $158\left[\mathrm{M}^{+}\right](100)$, 130 (85), 84 (52), 66 (65); HR-EIMS $m / z 158.0853$ (calc for $\mathrm{C}_{10} \mathrm{H}_{10} \mathrm{~N}_{2} 158.0842$ ); ${ }^{1} \mathrm{H}$ and ${ }^{13} \mathrm{C}$ NMR (DMSO- $d_{6} ; 500 \mathrm{MHz}$ for ${ }^{1} \mathrm{H}$ ) see Table 1 .

2,2-Dimethyl-pyrrolo-1,2-dihydroquinoline (4). Purplish blue glass; UV (MeOH) $\lambda_{\max }(\log \varepsilon) 230$ (4.41), 322 (3.67) nm; IR (thin film) $v_{\max } 3400,2905,1520,1450,1400 \mathrm{~cm}^{-1}$; EIMS $\mathrm{m} / z$ (\% relative intensity) $198\left[\mathrm{M}^{+}\right]$(15), 183 (100); HR-EIMS $m / z$ 198.1122 (calc for $\mathrm{C}_{13} \mathrm{H}_{14} \mathrm{~N}_{2}$ 198.1154); ${ }^{1} \mathrm{H}$ and ${ }^{13} \mathrm{C}$ NMR (DMSO- $d_{6} ; 500 \mathrm{MHz}$ for $\left.{ }^{1} \mathrm{H}\right)$ see Table 2.

\subsection{Bioactivity determination}

The AChE inhibitory assay was conducted (in triplicate) according to the protocol described by Ingkaninan et al [20, modified from 21]. To a solution of $125 \mu \mathrm{L}$ 5,5'-dithiobis[2-nitrobenzoic acid] (3 $\mathrm{mM}), 25 \mu \mathrm{L}$ acetylthiocholine iodide (1.5 mM), $50 \mu \mathrm{L}$ Tris-HCl buffer (pH 8.0; $5.0 \mathrm{mM}$ ), and $25 \mu \mathrm{L}$ of each tested compound in Tris-HCl buffer was added $25 \mu \mathrm{L}$ Torpedo californica AChE (type VI-S, EC 3.1.1.7; $0.28 \mathrm{U} \mathrm{mL}^{-1}$; Sigma ${ }^{\circledR}$ ). The developing yellow color was measured at $405 \mathrm{~nm}$ over 2 min with a 5-s interval using a CERES UV900C microplate reader (Bio-Tek Instrument). The resulting velocity was calculated and used for the determination of the enzyme activity. The $\mathrm{IC}_{50}$ of each compound was calculated using Prism ${ }^{\circledR}$ software (Graph Pad Inc.), and was referred to the potency of standard galantamine $\left(\mathrm{IC}_{50} 0.6 \pm 0.1 \mu \mathrm{M}\right)$.

Cytotoxicity determination was performed according to the sulphorrhodamine B assay protocol described in [22]. The paneled cancer cell lines used here include MCF-7 (human breast adenocarcinoma), HeLa (human cervical carcinoma), KB (human oral epidermoid carcinoma), and HT-29 (colorectal carcinoma). The potency was referred to camptothecin as a standard reference $\left(\mathrm{IC}_{50} \mathrm{~s} 0.6-6 \times 10^{-6} \mu \mathrm{M}\right)$. 


\section{Acknowledgements}

This work is financially supported by the Thailand Research Fund (DBG5080024 and MRG4880154). O.S. thanks the TRF/BIOTEC Special Program for Biodiversity Research and Training Program (BRT T_650006) and the Academic Excellence Enhancing Program in Pharmaceutical Sciences for her thesis supporting grants. BNPME is supported by a grant for the Center of Excellence, Commission on Higher Education, Thailand.

\section{References and Notes}

1. Racchi, M.; Mazzuucchelli, M.; Porrello, E.; Lanni, C.; Govoni, S. Acetylcholinesterase Inhibitors: Novel Activities of Old Molecules. Pharmacol. Res. 2004, 50, 441-451.

2. Lanari, A.; Amenta, F.; Silvestrelli, G.; Tomassoni, D.; Parnetti, L. Neurotransmitter Deficits in Behavioral and Psychological Symptoms of Alzheimer's Disease. Mech. Ageing Dev. 2006, 127, 158-165.

3. Srisukchayakul, P.; Suwannachart, C.; Sangnoi, Y.; Kanjana-opas, A.; Hosoya, S.; Yokota, A.; Arunpairojana, V. Rapidithrix thailandica gen. nov., sp. nov., A Marine Gliding Bacteria Isolated from Andaman Sea, the Southern Coastline of Thailand. Int. J. Syst. Evol. Microbiol. 2007, 54, 2275-2279.

4. Kanjana-opas, A.; Panphon, S.; Fun, H.-K.; Chantrapromma, S. 4-Methyl-3H-pyrrolo[2,3c]quinoline. Acta Cryst. E. 2006, 62, o2728-o2730.

5. Chang, C. J.; Floss, H. G.; Hook, D. J.; Mabe, J. A.; Manni, P. E.; Martin, L. L.; Schröder, K.; Shieh, T. L. The Biosynthesis of the Antibiotic Pyrrolnitrin by Pseudomonas aureofaciens. J. Antibiot. 1981, 34, 555-566.

6. van Pée, K.-H.; Salcher, O.; Fischer, P.; Bokel, M.; Lingens, F. The Biosynthesis of Brominated Pyrrolnitrin Derivatives by Pseudomonas aureofaciens. J. Antibiot. 1983, 36, 1735-1742.

7. Zhou, P.; Mocek, U.; Siesel, B.; Floss, H. G. Biosynthesis of Pyrrolnitrin. Incorporation of ${ }^{13} \mathrm{C},{ }^{15} \mathrm{~N}$ Double-Labelled D- and L-Tryptophan. J. Basic Microbiol. 1992, 32, 209-214.

8. Gerth, K.; Trowitzsch, W.; Wray, V.; Höfle, G.; Irschik, H.; Reichenbach, H. Pyrrolnitrin from Myxococcus fulvus (Myxobacterales). J. Antibiot. 1982, 35, 1101-1103.

9. El-Banna, N.; Winkelmann, G. Pyrrolnitrin from Burkholderia capacia: Antibiotic Activity against Fungi and Novel Activities against Streptomycetes. J. Appl. Microbiol. 1998, 85, 69-78.

10. Pohanka, A.; Broberg, A.; Johansson, M.; Kenne, L.; Lavenfors, J. Pseudotrienic Acids A and B, Two Bioactive Metabolites from Pseudomonas sp. MK381-IODS. J. Nat. Prod. 2005, 68, 13801385.

11. Kirner, S.; Hammer, P. E.; Hill, D. S.; Altmann, A.; Fischer, I.; Weislo, L. J.; Lanahan, M.; van Pée. K.-H.; Ligon, J. M. Functions Encoded by Pyrrolnitrin Biosynthesis Genes from Pseudomonas fluorescens. J. Bacteriol. 1998, 180, 1939-1943.

12. Muñoz-Ruiz, P.; Rubio, L.; García-Palomero, E.; Dorrensoro, I.; del Monte-Millán, M.; Valenzuela, R.; Usán, P.; de Austria, C.; Bartolini, M.; Andrisano, V.; Bidon-Chanal, A.; Orozco, M.; Luque, F. J.; Medina, M.; Martínez, A. Design, Synthesis, and Biological Evaluation of Dual Binding Site Acetylcholinesterase Inhibitors: New Disease-Modifying Agents for Alzheimer's Disease. J. Med. Chem. 2005, 48, 7223-7233. 
13. da Silva, C. H. T. P.; Campo, V. L.; Carvalho, I.; Taft, C. A. Molecular Modeling, Docking and ADMET Studies Applied to the Design of a Novel Hybrid for Treatment of Alzheimer's Disease. J. Mol. Graph. Model. 2006, 25, 169-175.

14. Hosoya, S.; Arunpairojana, V.; Suwannachart, C.; Kanjana-opas, A.; Yokota, A. Aureispira marina gen. nov., sp., nov., a Gliding Arachidonic Acid-Containing Bacterium Isolated from the Southern Coastline of Thailand. Int. J. Syst. Evol. Microbiol. 2006, 56, 2931-2935.

15. Zhang, P. L.; Wang, Y. H.; Fang, M. X.; Stackebrandt, E.; Ding, B. Y. Improved Methods of Isolation and Purification of Myxobacteria and Development of Fruiting Body Formation of Two Strains. J. Microbiol. Meth. 2003, 54, 21-27.

16. Reichenbach, H. In The Prokaryotes; Balows,A.; Truper, H. G.; Dworkin, M.; Harder, W.; Schleifer, K. H., Eds.; Springer-Verlog: New York, 1992; Vol. 4, The Order Cytophagales, pp 3631-3675.

17. Hall, T. A. Bioedit: A User-Friendly Biological Sequence Alignment Editor and Analysis Program for Window 95/98/NT. Nucleic Acids Symp. Ser. 1999, 41, 765-768.

18. Suzuki, Y.; Ojia, M.; Sakagami, Y.; Fudou, R.; Yamanaka, S. Cystothiazoles C-F, New Bithiazole-Type Antibiotics from the Myxobacterium Cystobacter fuscus. Tetrahedron. 1998, 54, 11399-11404.

19. Vobis, G. In The Prokaryotes; Balows,A.; Truper, H. G.; Dworkin, M.; Harder, W.; Schleifer, K. H., Eds.; Springer-Verlog: New York, 1992; Vol. 2, The Genus Actinoplanes and Related Genera, pp 1031-1060.

20. Ingkaninan, K.; Changwijit, K.; Suwanborirux, K. Vobasinyl-Iboga Bisindole Alkaloids, Potent Acetylcholinesterase Inhibitors from Tabernaemontana divaricata Root. J. Pharm. Pharmacol. 2006, 58, 847-852.

21. Ellman, G. L.; Courtney, K. D.; Andres, V., Jr.; Featherstone. R. M. A New and Rapid Colorimetric Determination of Acetylcholinesterase Activity. Biochem. Pharmacol. 1961, 7, 8895.

22. Skehan, P.; Storeng, R.; Scudiero, D.; Monks, A.; McMahan, J.; Vistica, D.; Warren, J. T., Bokesch, H.; Kenney, S. New Colorimetric Cytotoxicity Assay for Anticancer-Drug Screening. $J$. Natl. Cancer Inst. 1990, 82, 1107-1112.

(C) 2008 by the authors; licensee Molecular Diversity Preservation International, Basel, Switzerland. This article is an open-access article distributed under the terms and conditions of the Creative Commons Attribution license (http://creativecommons.org/licenses/by/3.0/). 